\title{
Principal Leadership in Increasing Teacher Job Satisfaction
}

\author{
Adnin $\mathrm{AS}^{*}$ \\ Magister of Educational Administration \\ Syiah Kuala University \\ Banda Aceh, Indonesia \\ *deninaceh@gmail.com
}

\author{
Murniati, Nasir Usman \\ School of Educational \\ Syiah Kuala University \\ Banda Aceh, Indonesia \\ Murniati@unsyiah.ac.id, Nasir@unsyiah.ac.id
}

\begin{abstract}
The purpose of this study was to analyze and describe in depth about the principal's leadership in creating teacher job satisfaction. The method used is qualitative descriptive text, so that this research can be carried out in depth and will produce products related to the leadership of the principal that is effective, efficient in the end has an impact on teacher job satisfaction. The results showed that the policy factors which were subsequently outlined in the form of a program so that it was carried out with a strategy of arousing enthusiasm, discipline and increasing a sense of responsibility would affect the job satisfaction of teachers in private senior high school inshafuddin Banda Aceh. The conclusion is to create teacher job satisfaction through leadership, the principal must have an intelligent mind so that the policy issued can touch the fundamental problems and after that the policy must be able to be described in the form of a program that is easy to understand and implement. These ways, significantly teacher job satisfaction can be created.
\end{abstract}

Keywords—leadership, principal, teacher job satisfaction

\section{INTRODUCTION}

Supriadi [1] states that, "from the results of the study, it is concluded that the leadership of the principal has a significant effect on teacher performance so that it is necessary to improve the leadership of the principal". Firmansyah [2] also said that, "in this study together, work environment variables and leadership have a significant influence on teacher job satisfaction". From the results of the research findings, it answers the problem or problem regarding teacher job satisfaction. Handayani [3] states that, "from the research results, it is found that the lack of teacher performance is caused by factors of leadership, motivation, and organizational culture".

Job satisfaction is an important factor to get optimal work results. According to Hasibuan [4] "job satisfaction is a pleasant emotional attitude and loves work. Therefore, when a person feels satisfaction at work, of course he will try as much as possible to the best of his ability to complete his job duties. This is based on the assumption that teachers work in addition to expecting benefits both material and non-material they also want what is in accordance with their expectations such as there is openness in the organization, there is attention, support, and appreciation. Creation that is achievement-oriented and concerned with workers can facilitate the achievement of the desired results.

Based on the results of the research and the theory above, it is necessary to conduct in-depth research regarding the role of the principal as a leader in increasing teacher job satisfaction. This not only has an impact on teachers but will also have an impact on student achievement. Supriadi [1] states that, "from the results of the study it is suggested that there is a positive and significant contribution of madrasah leadership to student achievement, and an increase in principal leadership is followed by an increase in student learning achievement"

The main purpose of education is to fulfill the promise of this nation's constitution which is stated in the body of the 1945 constitution related to education guarantee for every nation's child and the purpose of education to create a person with noble character. It is not enough to stop there, the national education system is reaffirmed that education is held to function to develop abilities and form a dignified national character in the framework of educating the nation, a dignified character is formed through education which develops the potential of students to become human beings who believe and have devotion to god almighty. One. This education will not run only with laws and other regulations, but there must be a variety of interventions and roles, and one of them is the role of the teacher.

Teachers have a duty to educate, teach and train. Educating means developing and developing life values, teaching means and developing knowledge, training skills in students. In carrying out duties and responsibilities, a teacher is required to have certain skills. These skills are part of teacher quality. This is contained in Law Number 14 of 2005 concerning Teachers and Lecturers, Article 8 Paragraph (1) stipulates that; teachers are required to have academic qualifications, competencies, educator certificates, be physically and mentally healthy, and have the ability to realize the goals of national education". The explanation above will run effectively and effectively and be directed by a school principal as a leader in the school. 
The principal is expected to be able to practice management functions, namely planning, organizing, actuating and controlling, this can improve teacher performance. These management functions will run synergistically with the role of the principal as educator, manager, administrator, supervisor, leader, innovator and motivator. In this case, the principal as someone who is given the task to lead the school, the principal is responsible for the achievement of school goals. The principal needs to have the ability to empower all existing human resources to achieve school goals. Especially with regard to school principals, teachers must have the ability to improve teacher performance, through empowering teacher human resources.

Mulyasa [5] states that; "The principal has a very important position in moving school management so that it can run in accordance with the demands of society and the development of the needs of the times, especially advances in science, technology, culture, and arts". It is said to be very important because it is closer and directly related to the implementation of education programs. So it can be that the achievement of educational programs and goals is influenced by the skills and wisdom of the principal.

The observations of researchers at the Inshafuddin private senior high school Banda Aceh show that teachers are not satisfied with the implementation of the supervision of the principal, so the teacher will work because they are forced and less enthusiastic, which is shown by negative attitudes because they are not satisfied, and this results in decreased work productivity. On the other hand, job satisfaction is also influenced by other things such as providing incentives, providing motivation, increasing abilities, good leadership styles. The conditions in the field reflect the condition that the teacher feels dissatisfied with his work, he will make many negative responses that hinder efforts to achieve organizational goals. The most extreme response is to leave the school where he teaches.

\section{RESEARCH METHODS}

The research approach used in this research is qualitative research. The subjects of this study were teachers and principals at Inshafuddin Banda Aceh private high school. data collection techniques that will be used in this study are the method of observation (observation), interviews, and documentation. All of these subjects were endeavored to be able to provide data about the leadership of the principal in increasing teacher job satisfaction, so as to support the achievement of primary data, the information was tracked on the subject. Data analysis in this study was carried out by following the procedure as proposed by Mille and Huberman in Sugiyono [6] namely: Data reduction, data display, data verification. The analysis steps are shown in the following figure:

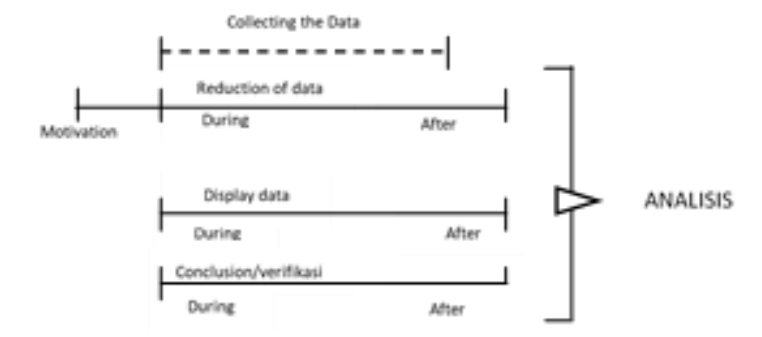

Fig. 1. Components of data analysis

\section{DISCUSSION RESUlTS}

\section{A. Principal's Policy in Increasing Teacher Job Satisfaction} at Inshafuddin Private Senior High School

The results of research conducted at the Inshafuddin Private Senior High School in Banda Aceh show that the principal is always carrying out his duties and roles as school principal always approaches waka and teachers as a kinship that promotes deliberation in solving problems that occur at school. In addition, the Principal revealed that the principal in admonishing teachers was carried out persuasively by verbal reprimanding steps, trying to discuss obstacles or problems, reprimanding with letters, making good decisions for teachers who had problems with work.

\section{B. The Principal's Program in Improving the Work of Private Senior High School Teachers in Inshafuddin Banda Aceh}

The results of research conducted at the Inshafuddin Private senior high school show that the principal puts forward the principal duties of the Principal, which are described in two major parts, namely:

1) Standard operation procedure for the duties of the principal: The principal as the highest leader in the school organization has a very complex task in determining the progress of the school. The complex duties of the principal can be classified into seven main points, namely: principal as educator, principal as manager, principal as administrator, principal as supervisor, principal as leader, principal as innovator and principal as motivator.

2) Interpersonal processes and approaches in carrying out duties as principal: Broadly speaking, the scope of the principal's duties can be classified into two main aspects, namely work in the field of school administration and work relating to educational professional development. To carry out this task as well as possible, there are three main types of skills that the principal as an educational leader must possess, namely technical skills (echnical skills), communication skills (human relations skills) and conceptual skills (conceptual skills). According to the perception of many teachers, the imperative for the leadership of the principal is primarily based on his ability to lead. 
From the school principal's program above, it can be interpreted through coaching for teachers and efforts to provide the learning needed by the principal as a communicator in charge of being an intermediary for finding instructions to teachers. The communication patterns from school are generally familial.

\section{The Principal's Strategy in Increasing Teacher Job Satisfaction at Inshafuddin Banda Aceh Private Senior High School}

The results showed that the principal of Inshafuddin Banda Aceh Private High School, namely:

1) Increasing motivation on working: The results showed that the principal of private senior high school inshafuddin Banda Aceh was able to integrate information in the school environment, strategies for achieving goals that were applied to work methods and systems, and work in a proportional, comprehensive, and sustainable manner, where the professional ability of teachers always needed actualized. The role of the principal is to help teachers understand issues and make wise decisions that can positively affect student education.

Based on the above opinion, it can be concluded that the type of an educational leader has a high ability in selecting leaders to increase teacher morale. $\mathrm{He}$ has democratic leadership, that the principal is able to influence other people to cooperate to achieve the goals that have been set by means of various activities that will be carried out jointly between the leadership and subordinates.

2) Improving discipline: In discipline there are elements which include behavior guidelines, consistent rules, punishment and rewards. Discipline is an orderly condition, when people who are members of a system are happy to obey the existing rules.

Fostering teacher discipline towards work is one of the coaching activities planned to assist teachers in doing work effectively. To obtain data on the leadership of school principals in improving teacher discipline in terms of fostering teacher discipline, namely the principal providing guidance to teachers to carry out educational activities effectively and efficiently, all education personnel must have high discipline in all areas of Yamin and Maisah [7] states that upholding discipline does not aim to reduce the freedom and independence of students but on the contrary wants to provide greater independence to students within the limits of their abilities".

Principal of private senior high school inshafuddin Banda Aceh in providing direct direction in fostering and improving teacher discipline. In every meeting, there is always a reminder of the importance of teacher discipline and the importance of obeying the teacher rules that have been made together. In daily activities as a principal, he tries his best to improve selfdiscipline in the hope that teachers can imitate and emulate him. However, on another occasion, the principal gave information that if in implementing a teacher who was less disciplined in fulfilling the stipulated conditions he would be firm in giving a warning or suggestion to the teacher.

This was done by the principal because the teacher was deemed to have violated the applicable rules and needed to be given a stronger warning. In every meeting the principal always reminds the importance of discipline in obeying the rules that have been made together in daily activities as the principal tries his best to improve self-discipline in the hope that it can be imitated and exemplified by teachers. In order to supervise teacher discipline, the principal also forms a special staff in the field of teacher discipline.

To increase discipline and job satisfaction. if there are teachers who come late to school and enter the class, the principal immediately reprimands and advises and makes absent attendance and controls each class if a teacher arrives late in entering the class. Teacher job satisfaction is a complex symptom that has various related factors, namely personal, social, cultural and economic. Teacher job satisfaction is also the result of various attitudes of a teacher towards his job and to factors related to his job. Teacher job satisfaction is the teacher's feelings about fun or not about work based on the teacher's expectations with the rewards given by the school

3) Increasing responsibility: Efforts made by the principal of Inshafuddin Banda Aceh private senior high school in increasing teacher responsibility are by creating a harmonious situation and cooperation between teachers, trying to fulfill the equipment needed by teachers in carrying out their duties, giving rewards and punishments and teachers in carrying out tasks not based on fear but a feeling of reluctance if you cannot complete the assigned task.

To increase the responsibility of each teacher, the principal provides greater opportunity and authority to teachers in accordance with their respective fields of study. The principal gives the opportunity to delegate to teachers according to their respective expertise. The principal gives the opportunity for authority to the teacher according to their respective expertise, for example sending the teacher to follow the reasoning.

The principal in making decisions and policies regarding the progress and development of the school as well as how to increase teacher responsibility in the form of decisions that are directly decided by the teacher only follows the advice and implements the decision because the decision is deemed by the principal to not necessarily involve the teacher, while decisions related to vision and mission of the school The principal upholds the values of togetherness to bring the school to a higher quality.

Effective leadership requires the ability to mobilize and motivate others to be willing to carry out orders. Thus implementing these functions by the principal so as to increase teacher job satisfaction, teacher job satisfaction is a complex symptom that has various related factors, namely personal, social, cultural and economic. Teacher job satisfaction is also a result of a teacher's various attitudes towards his job and to 
factors related to his job. Teacher job satisfaction is the teacher's feelings about fun or not about work based on teacher expectations in exchange for the rewards given by the school.

\section{Factors Affecting Teacher Job Satisfaction at Inshafuddin Private Senior High School}

From the results of research at the inshafuddin private senior high school in Banda Aceh, regarding the teacher job satisfaction factor, namely: The principal does not hesitate to give appreciation for maximum work results but also does not hesitate in correcting teachers or other employees if he sees things that are not suitable. The principal continues to encourage the achievements of teachers and staff by providing motivation to increase morale. according to their respective abilities. The principal also tries to create a work atmosphere that is full of kinship, namely the existence of mutual trust. Mutual respect and mutual respect.

The school principal also supervises to ensure whether the teacher carries out his duties as mandated, whether every officer such as laboratory and library staff performs tasks according to their main duties and functions, whether the administrative guard provides excellent service, whether the counselor guides students are able to overcome their learning difficulties, and etc. If it is appropriate, then the principal can provide guidance by motivating, but if it is not appropriate then corrective steps are taken according to the correct procedure.

From the description above, it can be concluded that the success of education is largely determined by the role of teacher performance in the world of education, the teacher bears the task and responsibility that is not light, namely where the teacher has an obligation to students so that students have noble and intelligent morals). This is done by a professional teacher because it is the satisfaction of the performance of each teacher. The teacher will feel satisfied if the students become smart, have good achievements, have good morals.

\section{CONCLUSION}

Based on the results of the research and discussion that has been presented, several conclusions can be drawn, as follows: in terms of policy, the policy of the principal of the Private High School Inshafuddin Banda Aceh in increasing teacher job satisfaction, namely holding meetings to take joint decisions in building a work culture in schools. Program, the principal in improving teacher work, namely the Principal Program in improving teacher work, namely trying to provide compensation both material and non-material that leads to job satisfaction.

As well as the welfare efforts of teachers and staff, among others, are to grant teachers and administrative staff rights, reward those who excel or have done a good job, foster family relationships between teachers / staff and their families. The principal's strategy in improving teacher work in Inshafuddin Private High School is the principal's strategy in improving teacher work, namely 1) Fostering teacher morale; 2) improve teacher work discipline in the form of punctuality to enter the classroom according to a predetermined schedule; and 3) Increasing teacher work responsibilities, principal leadership creates a situation and harmonious cooperation between teachers, trying to meet the equipment needed by teachers in implementing it. Factors that affect the work of teachers at inshafuddin private high school Banda Aceh, namely giving appreciation for maximum work results but also not hesitate in correcting teachers if there are things that are not suitable and continue to encourage the achievement of teachers and staff by providing motivation to increase morale.

\section{REFERENCES}

[1] E. Supriadi "Contribution of Madrasah Principal Leadership, Teacher Work Ability and Organizational Climate on Learning Achievement of Students at MTs Negeri Jakarta Selatan," Journal of Educational Management Research, vol. 1, no. 2, pp. 1-18, 2016.

[2] F. Firmansyah, "The Effect of Work Environment, Compensation, and Leadership on Job Satisfaction of Teachers and Employees in SMA Wachid Hasyim Surabaya," vol. 3, no. 1, pp. 93-105, 2008

[3] T. Handayani, "The Influence of Principal Leadership, Teacher Motivation, and Organizational Culture on Teacher Performance at SMA Negeri Wonosobo," Journal of Education Management Accountability, vol. 3, no. 2, pp. 264-277, 2015.

[4] S.P. Hasibuan, Human Resource Management. Jakarta: PT. Bumi Aksara, 2013.

[5] E. Mulyasa, Manajemen \& Kepemimpinan Kepala Sekolah, Jakarta: Bumi Aksara, 2013.

[6] Sugiyono, Understanding Qualitative Research. Bandung: Alfabeta, 2013.

[7] Yamin and Maisah, Classroom Learning Management. Jakarta : Gaung Persada, 2009 